\title{
The effect of supplementation with gold of pleasure (Camelina sativa) cake on the fatty acid profile of ewe milk and yoghurt produced from it
}

\author{
R. Danków' ${ }^{1}$, J. Pikul', J. Wójtowski²,5, D. Cais-Sokolińska', J. Teichert', E. Bagnicka ${ }^{4}$, \\ A. Cieślak ${ }^{3}$ and M. Szumacher-Strabel ${ }^{3}$ \\ Poznań University of Life Sciences \\ ${ }^{1}$ Department of Dairy Technology, Faculty of Food Science and Nutrition \\ Wojska Polskiego 31, 60-624 Poznań, Poland \\ ${ }^{2}$ Department of Small Mammalian Breeding and Raw Materials of Animal Origin, Słoneczna 1, 62-002 Suchy Las, Poland \\ ${ }^{3}$ Department of Animal Nutrition and Feed Management, Wołyńska 33, 60-637 Poznań, Poland \\ ${ }^{4}$ Institute of Genetics and Animal Breeding, Polish Academy of Sciences \\ Jastrzębiec, Postępu 36A, 05-552 Magdalenka, Poland
}

KEY WORDS: sheep, Camelina sativa, milk, yoghurt, fatty acids

Received: 23 October 2014

Revised: 28 May 2015

Accepted: 9 September 2015

${ }^{5}$ Corresponding author:

e-mail: jacwojto@gmail.com

\begin{abstract}
The content of bioactive components in dairy products depends mainly on their content in raw milk and on the technological production process. The experiments were performed on the milk collected from dairy sheep receiving concentrated feed without (control group) and with a $12 \%$ addition of gold of pleasure (experimental group). Adding Camelina sativa cake to the feed led to an increase in the share of monounsaturated fatty acids (MUFA), including trans MUFA, and polyunsaturated fatty acids in raw milk and in the produced yoghurt, even after 21 days of refrigerated storage. The percentage of conjugated dienes of $\mathrm{C}_{18.2}$ acid was more than 3 times higher. There was no difference in the processability of the experimental milk and the milk from the sheep in the control group. The increased share of bioactive components in milk did not cause any changes in acidity, consistency or colour (assessed instrumentally), nor in the taste, smell and consistency (assessed sensorially) of the produced yoghurt.
\end{abstract}

\section{Introduction}

Recent years have seen increased consumer awareness of the nutritional and health-promoting qualities foods significantly influencing health. The beneficial effect of the bioactive components contained in milk and its products on consumer health is well documented (Myers, 2007). The level of bioactive components in raw milk, especially fatty acids, is determined, among others, by the animal species, diet and stage of lactation (Wójtowski et al., 2003; Pikul et al., 2008; Markiewicz-Kęszycka et al., 2014). Sheep milk has a greater nutritional value than cow, or even goat milk. It is characterized by a higher content of individual nutrients, as well as bioactive components, such as immunoglobulins, lysozyme and lactoferrin (Blasi et al., 2008). Sheep milk fat contains more conjugated dienes of linoleic acid (CLA), $\mathrm{mg} \cdot \mathrm{g}^{-1}:$ (12.38) than cow (8.71) and goat milk (6.67). 
Sheep milk fat is also characterized by the highest content of cis-9, trans-11 CLA isomer (Wójtowski et al., 2003). CLA has a particular biological activity. It contributes to the reduction of unwanted LDLcholesterol, has antioxidant properties and strengthens the immune system of the whole organism. The capacity to synthesize CLA is also present in lactic acid bacteria (LAB), which thus contribute to its raised level in dairy products, especially fermented drinks. The content of CLA produced by bacteria depends on the type of bacteria strain used, type of milk and incubation conditions (Mel'uchová et al., 2008). The component of milk that is the most sensitive to changes due to feeding are the fatty acids contained in milk fat and the fat-soluble vitamins and carotenoids (Collomb et al., 2006).

Appropriately selected components of the feed ration in ruminants may constitute a source of substrates for microorganisms colonizing the rumen that produce biologically active compounds as a result of nutrient fermentation processes (Sieber et al., 2004). An example of compounds exhibiting high biological activity in the milk of these animals is the conjugated dienes of linoleic acid, which (depending on their form) may prevent the development of many diseases of civilization (Park, 2009). Feed ration components rich in polyenic fatty acids include products obtained in the course of biofuel production from seeds of oil crops (cakes and meals). While the effect of adding rapeseed and linseed cake on the composition of fatty acids in the milk of small ruminants is relatively well known (Mughetti et al., 2012), there are no data on the application of cake from gold of pleasure (Camelina sativa), an oil crop known for centuries, which may be grown on poorer soils unsuitable for growing rape as an energy crop.

Camelina sativa is an oilseed crop of the Brassicaceae (Cruciferae) family (Zubr, 1997). The recent search for new sources of essential fatty acids, particularly n-3 fatty acids, has led to a renewed interest in it. Camelina seeds contain about 39\% fat, $30 \% \alpha$-linolenic acid and $26 \%$ crude protein. A coproduct obtained from camelina seed after oil extraction, gold of pleasure cake, is finding alternative use in animal diets due its high oil content (CaisSokolińska et al., 2015). The oil contains about $90 \%$ unsaturated fatty acids. Approximately $50 \%$ of the total fatty acids are polyunsaturated, e.g., linoleic acid $\left(18: 2_{n-6}\right)$ and $\alpha$-linolenic acid $\left(18: 3_{n-3}\right)$.

Because of its rich chemical composition, sheep milk is an excellent raw material for the production of fermented drinks. The large share (up to $18 \%$ ) of dry matter in sheep milk does not require the use of any thickeners, which makes the drinks fully natural and free of additives. Initially, yoghurt used to be produced from sheep and goat milk, mainly in the Balkans, Turkey and the Middle East. Currently, sheep milk yoghurt is produced on an industrial scale also in Mediterranean countries. In Poland, small quantities of yoghurt are produced, chiefly using the thermostat method (Danków and Pikul, 2011). Yoghurt from sheep milk may contain between $15 \%$ and $21 \%$ dry matter, including from $4.5 \%$ to over $8 \%$ fat, which determines its very good nutritional and energy value. It is characterized by a dense, smooth and stable curd, compact consistency, absence of a whey layer, slightly sour taste and fresh scent. The proper selection of inoculation methods allows modification of acidity, the amount of flavouring compounds, as well as sensory attributes of yoghurt. By introducing probiotic bacteria, such as Lactobacillus acidophilus and bifidobacteria, it is possible to maintain or restore the intestinal microflora.

The aim of the study was to establish the potential for modification of the fat composition of ewe's milk and yoghurt produced from it by supplementation of $12 \%$ Camelina sativa cake to the feed ration.

\section{Material and methods}

\section{Animals, feeding and sample collection}

The raw material was collected from 32 milking ewes from the Polish Dairy sheep line 05 . The animals had a mean body weight of $60 \pm 3 \mathrm{~kg}$ and were aged 3 and 4 years (the second and third lactation).

The ewes in this experiment were fed with basal diet (control) and basal diet plus $12 \mathrm{~g} \cdot 100 \mathrm{~g}^{-1}$ of C. sativa (CS) concentrate dry matter. The amount of CS offered was established on the basis of a series of previous experiments with gold of pleasure supplementation to ewe diets, when $10 \mathrm{~g} \cdot 100 \mathrm{~g}^{-1}$ and $20 \mathrm{~g} \cdot 100 \mathrm{~g}^{-1}$ of CS in concentrate dry matter improved sheep milk fatty acid composition (Szumacher-Strabel et al., 2011).

All the ewes were at the identical stage of lactation. Up to day 89 of lactation the animals $(\mathrm{n}=32)$ were fed the basal diet. Starting from day 90 of lactation, for the next 30 days the sheep in the control group $(n=16)$ continued to receive the basal diet, while the animals in the experimental group (CS) were fed the experimental diet, i.e. basal diet plus $12 \mathrm{~g} \cdot 100 \mathrm{~g}^{-1}$ of CS in concentrate dry matter (DM). After a 30-day period of adaptation to the experimental diet, on days 120 to 123 of lactation individual milk samples were collected during the morning and evening milking $(2 \times 250 \mathrm{ml})$ from all 
ewes $(n=32)$ for chemical analyses and for the production of yoghurt. From this material, 10 yoghurt batches of 51 each were produced, with five batches from the milk of each ewe group. The analyses were performed in two replicates.

Ewes were machine milked twice a day. Daily samples of milk from individual ewes were prepared by mixing morning and evening milking (1:1).

During the experiment, the ewes were fed $1 \mathrm{~kg}$ concentrate and $2.4 \mathrm{~kg}$ lucerne $/$ grass silage and meadow hay (DM basis) per ewe per day. Concentrates were individually fed in two equal portions during milking, while chopped lucerne hay was provided in individual box feeders twice daily (07:00 and 18:00). Ewes had free access to water and a mineral saltlick.

The basic composition and nutritive value of the used breeder mashes and forages are given in Tables 1 and 2 .

The concentrates offered to the sheep had on average 0.99 UFM (unit for milk production), $115 \mathrm{~g}$ PDIN (protein truly digestible in the small intestine depending on the $\mathrm{NH}_{3} \mathrm{~N}$ amount) and $107 \mathrm{~g}$ PDIE (protein truly digestible in the small intestine depending on energy amount). The chemical composition ( $\mathrm{g} \cdot \mathrm{kg}^{-1}$ of DM) of lucerne/grass silage and meadow hay used in the experiment was: dry matter 51.26 and 90.96 , crude protein 8.14 and 10.17 , crude fat 1.46 and 1.37 , and neutral detergent fibre (NDF) 44.97 and 48.39, respectively and

Table 1. Ingredients, basic composition and nutritive value of concentrates

\begin{tabular}{|c|c|c|}
\hline \multirow{2}{*}{ Indices } & \multicolumn{2}{|l|}{ Group } \\
\hline & control & $\mathrm{CS}^{1}$ \\
\hline \multicolumn{3}{|l|}{ Ingredient, $\mathrm{g} \cdot \mathrm{kg}^{-1} \mathrm{DM}$} \\
\hline wheat & 700 & 700 \\
\hline wheat bran & 80 & 80 \\
\hline rapeseed extracted meal & 200 & 80 \\
\hline Camelina sativa cake (CS) & 0 & 120 \\
\hline minerals and vitamins & 20 & 20 \\
\hline \multicolumn{3}{|l|}{ Basic composition, $\mathrm{g} \cdot \mathrm{kg}^{-1}$} \\
\hline dry matter & 88.49 & 91.63 \\
\hline organic matter & 83.25 & 87.50 \\
\hline crude ash & 5.24 & 4.13 \\
\hline crude protein & 17.20 & 17.95 \\
\hline crude fibre & 5.13 & 4.83 \\
\hline crude fat & 3.46 & 4.45 \\
\hline $\mathrm{NDF}^{2}$ & 15.39 & 15.71 \\
\hline \multicolumn{3}{|l|}{ Nutritive value, per $\mathrm{kg}$ of DM } \\
\hline UFM $^{3}$ & 0.99 & 0.99 \\
\hline $\mathrm{PDIN}^{4}, \mathrm{~g}$ & 115.4 & 116.1 \\
\hline $\mathrm{PDIE}^{5}, \mathrm{~g}$ & 106.8 & 107.4 \\
\hline
\end{tabular}

${ }^{1} \mathrm{CS}$ - with Camelina sativa; ${ }^{2} \mathrm{NDF}$ - neutral-detergent fibre; ${ }^{3} \mathrm{UFM}$ unit for milk production ( $1700 \mathrm{kcal} \mathrm{EN}$ ); ${ }^{4} \mathrm{PDIN}$ - protein truly digestible in the small intestine depending on $\mathrm{NH}_{3} \mathrm{~N}$ amount; ${ }^{5} \mathrm{PDIE}$ - protein truly digestible in the small intestine depending on energy amount
Table 2. Basic composition and nutritive value of lucerne/grass silage and meadow hay

\begin{tabular}{|c|c|c|}
\hline Indices & $\begin{array}{l}\text { Lucerne/grass } \\
\text { silage }\end{array}$ & $\begin{array}{l}\text { Meadow } \\
\text { hay }\end{array}$ \\
\hline \multicolumn{3}{|c|}{ Ingredients, $\mathrm{g} \cdot \mathrm{kg}^{-1} \mathrm{DM}$} \\
\hline dry matter & 51.26 & 90.96 \\
\hline crude ash & 7.42 & 6.86 \\
\hline crude protein & 8.14 & 10.17 \\
\hline crude fibre & 11.31 & 28.39 \\
\hline crude fat & 1.46 & 1.37 \\
\hline $\mathrm{NDF}^{1}$ & 44.97 & 48.39 \\
\hline \multicolumn{3}{|c|}{ Nutritive value, per $\mathrm{kg}$ of fresh matter } \\
\hline UFM $^{2}$ & 0.28 & 0.64 \\
\hline $\mathrm{PDIN}^{3}, \mathrm{~g}$ & 28 & 66 \\
\hline $\mathrm{PDIE}^{4}, \mathrm{~g}$ & 23 & 73 \\
\hline
\end{tabular}

1,2,3,4 see Table 1

neutral detergent fibre (NDF) 449 and 484, respectively. Moreover, Camelina sativa cake contained (g $\cdot \mathrm{kg}^{-1} \mathrm{DM}$ ): dry matter 926, organic matter 871, crude protein 305 , crude fibre 102 and crude fat 139 , and the following fatty acids (profile in percentage): $\mathrm{C}_{16: 0}$ (7.3), $\mathrm{C}_{18: 1}$ cis-9 (16.1), $\mathrm{C}_{18: 2}$ cis-9 cis-12 (26.2), $\mathrm{C}_{18: 3}$ cis-9 cis-12 cis-15 (38.8), $\mathrm{C}_{20: 1}$ (11.6).

\section{Physicochemical analysis}

Samples of concentrates and lucerne/grass silage were collected every week and analysed according to the AOAC (2007) for dry matter (DM; method No. 934.01), ash (AS; method No. 942.05) and crude fibre (method No. 978.10). Crude protein (CP) was determined with the use of a Kjel-Foss Automatic 16210 analyzer (A/SN. Foss Electric, Hillerød, Denmark; method No. 976.05), while crude fat (CF) was tested with a Soxtec System HT analyzer (Tecator AB, Horanas, Sweden; method No. 973.18). NDF was estimated by the method of van Soest et al. (1991). The fatty acid composition of CS after extraction was determined in a gas chromatograph (GS; Varian Star CP 3800; Varian Analytical Instruments, Walnut Creek, CA, USA) equipped with a flame ionization detector and a CP-Sil 88 silica capillary column $(100 \mathrm{~m} 90.25 \mathrm{~mm}$ id, $0.20 \mathrm{~lm}$ film thickness; Chrompack, Varian, Middleburg, the Netherlands), according to the protocol described by Cieślak et al. (2009). Hydrogen was used as a carrier gas at a constant flow of $30.0 \mathrm{ml} \cdot \mathrm{min}^{-1}$ and a split ratio of 1:10. The oven temperature was programmed as follows: initially $175^{\circ} \mathrm{C}$ for $25 \mathrm{~min}$, then increasing at $5^{\circ} \mathrm{C} \cdot \min ^{-1}$ to $235^{\circ} \mathrm{C}$. The fatty acid peaks were identified by comparison with the retention times of known standards (FAME Mix; Supelco-SigmaAldrich Co., St. Louis, MO, USA), and according to Collomb and Bühler (2000). Fatty acid standards 
Supelco (Supelco-Sigma-Aldrich Co., St. Louis, MO, USA,) were used to create calibration curves for the quantification of $\mathrm{C}_{18: 0}, \mathrm{C}_{18: 1}$ trans $9, \mathrm{C}_{18: 1}$ cis 9 , and $\mathrm{C}_{18: 2}$.

Using standard methods, the following parameters were measured and determined for raw milk collected from each group of animals: fat, protein, lactose, mineral substances and dry matter contents (AOAC, 1995). Active acidity was measured with a Hanna Instruments HI 98230 pH-meter (Hanna Instruments, Woodnsocket, RI, USA), potential acidity was determined using the titration method, with the results given in ${ }^{\circ} \mathrm{SH}$. The energy value of milk was also calculated. The somatic cell count and total bacterial count, were measured using an IBCM BENTLEY device (BENTLEY Instruments, Inc., Chaska, MN, USA). Lactic acid bacteria were counted according to ISO 6611 (2004).

Milk and yoghurt samples $(10 \mathrm{ml})$ after extraction were analysed for fatty acid profiles using a gas chromatograph (Varian Star CP 3800, Varian Analytical Instruments, Walnut Creek, CA, USA) fitted with a flame ionization detector and a $100 \mathrm{~m}$ fused-silica capillary column $(0.25 \mathrm{~mm}$ i.d. $)$, coated with $0.2 \mu \mathrm{m}$ CP-Sil 88 (Chrompack, Varian, Chrompack, Varian, Middleburg, the Netherlands). Nonadecanoic acid $\left(\mathrm{C}_{19: 0}\right.$; Sigma Chemical Co., St. Louis, MO, USA) was used as the internal standard. Observed peaks were identified by the comparison of retention times with appropriate fatty acid methyl ester standards (37 FAME Mix, conjugated LA; Supelco, Supelco-Sigma-Aldrich Co., St. Louis, MO, USA; Supelco). Moreover, the CLA peaks were identified by comparison with retention times of the reference standard (conjugated LA methyl esters, a mixture of cis and trans-9,11 and 10, 12 octadecadienoic acid methyl esters; Sigma, Supelco-Sigma-Aldrich Co., St. Louis, MO, USA) and according to Collomb and Bühler (2000), using a Varian Workstation (Version 5.31).

Prior to statistical verification of analytical results, the fatty acids identified in raw milk and yoghurt were grouped into the following categories:

- $\quad \operatorname{SFA}\left(\mathrm{C}_{4: 0} ; \mathrm{C}_{6: 0} ; \mathrm{C}_{8: 0} ; \mathrm{C}_{10: 0} ; \mathrm{C}_{12: 0} ; \mathrm{C}_{13 \mathrm{iso}} ; \mathrm{C}_{14: 0} ;\right.$ $\mathrm{C}_{15: 0} ; \mathrm{C}_{15 \text { iso }} ; \mathrm{C}_{16: 0} ; \mathrm{C}_{17: 0} ; \mathrm{C}_{17 \mathrm{iss}} ; \mathrm{C}_{18: 0} ; \mathrm{C}_{19: 0} ;$ $\left.\mathrm{C}_{20: 0} ; \mathrm{C}_{22: 0} ; \mathrm{C}_{24: 0}\right)$

- MUFA $\left(\mathrm{C}_{14: 1} ; \mathrm{C}_{16: 1} ;\right.$ MUFA cis; MUFA trans; $\left.\mathrm{C}_{20: 1} ; \mathrm{C}_{22: 1} ; \mathrm{C}_{24: 1}\right)$

- MUFA cis $\left(\mathrm{C}_{18: 1 \mathrm{c} 9} ; \mathrm{C}_{18: 1 \mathrm{cl1} 11} ; \mathrm{C}_{18: 1 \mathrm{lc} 12} ; \mathrm{C}_{18: 1 \mathrm{cl} 13}\right.$; $\left.\mathrm{C}_{18: 1 \mathrm{c} 14} ; \mathrm{C}_{18: 1 \mathrm{c1} 15}\right)$

- $\quad$ MUFA trans $\left(\mathrm{C}_{18: 11 t} ; \mathrm{C}_{18: 1 \mathrm{t11} 1} ; \mathrm{C}_{18: 1 \mathrm{t11} 1} ; \mathrm{C}_{18: 1 \mathrm{t1} 2}\right.$; $\mathrm{C}_{18: 1115}$ )
- PUFA $\left(\mathrm{C}_{18: 2 \mathrm{2c} 9 \mathrm{c} 12} ; \mathrm{C}_{18: 2 \mathrm{2c} 9 \mathrm{c15}} ; \mathrm{C}_{18: 2 \mathrm{c} 9 \mathrm{t11}} ; \mathrm{C}_{18: 2 \mathrm{2t10c12}}\right.$; $\left.\mathrm{C}_{18: 3 \mathrm{cc} \mathrm{cl} 12 \mathrm{c} 15} ; \mathrm{C}_{20: 3} ; \mathrm{C}_{20: 4} ; \mathrm{C}_{22: 5} ; \mathrm{C}_{22: 6}\right)$

- $\operatorname{CLA}\left(\mathrm{C}_{18: 2 \mathrm{cst} 11} ; \mathrm{C}_{18: 2 \mathrm{t} 10 \mathrm{c} 12}\right)$

\section{Yoghurt manufacturing}

Yoghurt was produced using the thermostat method. Whole non-standardized processing milk was heated to $45^{\circ} \mathrm{C}$ and clean skimmed in a centrifuge. It was then subjected to heat treatment at $95^{\circ} \mathrm{C}$ with a retention period of about $15 \mathrm{~min}$. The pasteurized milk was then cooled to the inoculation temperature between 43 and $45^{\circ} \mathrm{C}$, and an ABT-1 'Direct Vat Set' starter culture was added, produced by Chr. Hansen (Hørsholm, Denmark) composed of lactic acid bacteria (Streptococcus thermophilus, Lactobacillus acidophilus LA5 and Bifidobacterium animalis ssp. Lactis BB-12) in the amount indicated by the manufacturer. After very thorough mixing, the milk with the added starter culture was put into $200 \mathrm{ml}$ unit packages (polypropylene cups) and then incubated at 43 to $45^{\circ} \mathrm{C}$ for about $4 \mathrm{~h}$, until active acidity expressed as $\mathrm{pH} 4.6$ was reached. The fermented drink was then left to ripen at $20^{\circ} \mathrm{C}$ for the first $2 \mathrm{~h}$, then its temperature was lowered to about $4^{\circ} \mathrm{C}$ and it was stored under refrigerated conditions at 4 to $6^{\circ} \mathrm{C}$ for 21 days. The contents of fat, protein, lactose and dry matter were determined in yoghurt produced using the thermostat method and its energy value was calculated. Its active acidity and titratable acidity were measured as well.

The viscosities of the samples $(50 \mathrm{ml})$ were measured at a temperature of $12 \pm 1^{\circ} \mathrm{C}$ using a HAAKE ViscoTester VT5 ${ }^{\mathrm{L}}$ rheoviscometre (Karlsruhe, Germany) equipped with an L3 rotor (Radius/Length $17.35 / 1.65 \mathrm{~mm}$, legacy product code VHA-315506E ) revolving at $60 \mathrm{rpm}$ (DIN 53019-1).

Texture and consistency were measured using a TA-XT plus Texturometer (Stable Micro Systems, Surrey, UK), equipped with an A/BE attachment having a compression disk with a diameter $\varnothing=35 \mathrm{~mm}$. The sample was placed inside a cylinder with an internal diameter $\varnothing=50 \mathrm{~mm}(75 \%$ full). Measuring conditions: distance $30 \mathrm{~mm}$, pretest $1.0 \mathrm{~mm} \cdot \mathrm{s}^{-1}$, post-test $10.0 \mathrm{~mm} \cdot \mathrm{s}^{-1}$. The test sample was prepared according to Marshall and Rawson (1999) and Brennan and Tudorica (2008). The behaviour of the sample during compression and return movement of the disk was analysed (sample compactness - the maximum positive force $\mathrm{F}^{+}$, consistency - the surface under the curve of $\mathrm{F}^{+}$force in time $t_{1}: t_{2}$, firmness - the maximum negative force $\mathrm{F}^{-}$, viscosity index - the surface under the curve of $F^{-}$force in time $t_{2}: t_{3}$ ). The results were recorded in 
Texture Exponent E32 version 4.0.9.0 (Stable Micro Systems, Surrey, UK).

The textural parameters: maximum force in compression (firmness), positive area of the curve (consistency), maximum negative force which indicates the resistance to withdrawal of the sample from the extrusion disc being lifted (cohesiveness) and negative area of the curve (viscosity index) were recorded. Consistency and index of viscosity are related parameters; consistency indicates the thickness of the sample, while the index of viscosity gauges the resistance of the sample to flow off the disc during back-extrusion. Triplicate measurements were taken on each sample.

The colour constituents of yoghurt were determined according to the CIELAB colour space as $\mathrm{L}^{*} \mathrm{a} * \mathrm{~b}$ coordinates using a X-Rite SP-60 spectrophotometer (Gorshkova, 2005).

\section{Yoghurt sensory examination}

Sensory examination of the taste, smell and texture of yoghurt was carried out using the profiling method (Isleten and Karagul-Yuceer, 2006). In it, the intensity of a stimulus is assessed along with the differences in the intensity of stimuli between the tested samples, and the values are scores on a 10-point scale, where 0 corresponds to the lowest intensity of the attribute and 10 to the highest. The assessment was carried out by a panel of 10 specifically trained and prepared people (Bárcenas et al., 2001).

\section{Statistical analysis}

The effect of feed supplementation on the milk production, fatty acid profile in milk, milk chemical composition and hygienic quality of milk was assessed statistically using analysis of variance based on a fixed model (SAS, 2008). Somatic cell count, total microbial count and lactic acid bacteria in milk were subjected to logarithmic transformation according to the formula $y=\log _{n}(x+10)$, where: $x-$ the actual number of somatic cells (total microbial count lactic acid bacteria) in milk. Data for fatty acid profiles and chemical composition of yoghurt was assessed using PROCMIXED of SAS (2008), with group effect and storage time (days) class variables with interaction diet $\times$ storage time. Means were compared using Scheffe's test. Differences were declared significant at $P$ $<0.05$. Only statistically significant interactions are presented in the tabular summaries of results.

Statistical analyses of apparent viscosity, consistency, cohesiveness, colour parameters ( $L * a * b *)$ and taste, flavour and consistency of yoghurt during refrigerated storage were determined using Statis- tica 8.0 software (StatSoft, Inc., 2011) at the level of significance $\alpha=0.05$.

\section{Results and discussion}

\section{Chemical composition, acidity and hygienic quality of sheep milk}

The basic chemical composition and acidity of milk collected from sheep in the control group (C) are similar to the figures given by Danków and Pikul (2011) and Wójtowski et al. (2003). The milk of sheep in the Camelina sativa (CS group) contained less fat and dry mater in comparison with the $\mathrm{C}$ group milk $(P<0.05$; Table 3$)$. The energy value of the milk from this group was lower than that from group $\mathrm{C}$. The other analysed parameters characterizing processability of milk did not differ between the groups. The hygienic quality of raw sheep milk in both groups (C and CS) did not differ. The requirements regarding the total somatic cell count and total plate count per cubic centimeter of milk were met. The milk satisfied the requirements of the standards regarding the presence of coliform bacteria as well as molds and yeasts.

Table 3. Milk yield, chemical composition, acidity and hygienic quality of sheep milk

\begin{tabular}{lccl}
\hline \multirow{2}{*}{ Analysed parameters } & Group & & \multirow{2}{*}{ SEM } \\
\cline { 2 - 3 } & control & $\mathrm{CS}^{1}$ & \\
\cline { 1 - 3 } Milk yield, $\mathrm{kg}$ & 34.76 & 35.05 & 2.15 \\
$\mathrm{~g} \cdot \mathrm{kg}^{-1}$ & & & \\
$\quad$ fat & $5.28^{\mathrm{b}}$ & $3.93^{\mathrm{a}}$ & 0.04 \\
$\quad$ protein & 4.08 & 3.92 & 0.04 \\
$\quad$ lactose & 5.98 & 5.75 & 0.06 \\
$\quad$ minerals & 0.74 & 0.82 & 0.02 \\
$\quad$ dry matter & $16.08^{\mathrm{b}}$ & $14.42^{\mathrm{a}}$ & 0.10 \\
Energy value, $\mathrm{kJ} \cdot \mathrm{kg}^{-1}$ & $367.36^{\mathrm{b}}$ & $309.97^{\mathrm{a}}$ & 0.13 \\
Active acidity, pH & 6.48 & 6.50 & 0.04 \\
Titratable acidity, ${ }^{\circ} \mathrm{SH}$ & 6.81 & 6.93 & 0.06 \\
Somatic cell count, $\mathrm{SCC} \cdot \mathrm{cm}^{-3}$ & $262 \cdot 10^{3}$ & $241 \cdot 10^{3}$ & $3.41 \cdot 10^{3}$ \\
CFU $\cdot \mathrm{cm}^{-3}$ & & & \\
$\quad$ total bacterial count & $145 \cdot 10^{3}$ & $125 \cdot 10^{3}$ & $2.23 \cdot 10^{3}$ \\
$\quad$ lactic acid bacteria & $6.8 \cdot 10^{3}$ & $6.2 \cdot 10^{3}$ & $1.80 \cdot 10^{3}$ \\
$\quad$ coliform bacteria & $<10$ & $<10$ & - \\
$\quad$ molds & 200 & 210 & 3.33 \\
$\quad$ yeasts & 500 & 490 & 4.66 \\
\hline
\end{tabular}

${ }^{1}$ see Table 1; a,b mean values within each row with different superscripts differ significantly at $\alpha=0.05$; SEM - standard error of the mean

\section{Fatty acid profiles of sheep milk and yoghurt during refrigerated storage}

Gold of pleasure supplementation of the diet of lactating sheep led to an increase in the percentage share of long-chain unsaturated fatty acids in milk (Table 4), in particular, of monounsaturated trans acids and conjugated dienes of $\mathrm{C}_{18: 2}$ acid. 
Table 4. Fatty acid profiles of sheep milk and yoghurt during refrigerated storage, $\mathrm{g} \cdot \mathrm{kg}^{-1}$ fatty acid methyl esters (FAME)

\begin{tabular}{|c|c|c|c|c|c|c|c|c|c|c|c|c|}
\hline \multirow{4}{*}{$\begin{array}{l}\text { Fatty acids, } \\
\% \text { FAME }\end{array}$} & \multicolumn{3}{|l|}{ Milk } & \multicolumn{9}{|l|}{ Yoghurt } \\
\hline & \multirow{2}{*}{\multicolumn{2}{|c|}{ group }} & \multirow{3}{*}{ SEM } & \multicolumn{9}{|c|}{ storage time, days } \\
\hline & & & & \multicolumn{2}{|l|}{1} & \multicolumn{2}{|l|}{7} & \multicolumn{2}{|l|}{14} & \multicolumn{2}{|l|}{21} & \multirow{2}{*}{ SEM } \\
\hline & control & $C S^{1}$ & & control & $\mathrm{CS}$ & control & CS & control & CS & control & CS & \\
\hline$C_{10: 0}$ & 6.65 & 6.60 & 0.41 & 6.90 & 6.66 & 6.61 & 6.51 & 6.69 & 6.72 & 6.72 & 6.70 & 0.46 \\
\hline $\mathrm{C}_{12: 0}$ & 4.72 & 5.03 & 0.29 & 4.51 & 4.34 & 4.16 & 4.20 & 4.60 & 4.05 & 4.63 & 4.15 & 0.31 \\
\hline $\mathrm{C}_{14: 0}$ & 13.07 & 12.92 & 0.51 & 13.17 & 12.85 & 12.53 & 12.52 & 12.45 & 12.32 & 12.51 & 12.37 & 0.68 \\
\hline$C_{16: 0}$ & 30.39 & 30.30 & 1.22 & 30.17 & 29.39 & 30.00 & 29.25 & 29.67 & 29.17 & 29.75 & 29.26 & 1.41 \\
\hline$C_{18: 0}$ & $8.28^{b}$ & $5.98^{a}$ & 0.49 & $9.00^{\mathrm{b}}$ & $6.61^{a}$ & $9.37^{b}$ & $6.67^{a}$ & $9.17^{b}$ & $6.81^{a}$ & $9.08^{b}$ & $6.75^{\mathrm{a}}$ & 0.54 \\
\hline$C_{18: 1 c 9}$ & $21.68^{b}$ & $18.55^{\mathrm{a}}$ & 0.92 & $21.65^{b}$ & $19.13^{a}$ & $21.96^{b}$ & $19.17^{a}$ & $21.80^{b}$ & $19.26^{a}$ & $21.69^{b}$ & $19.31^{a}$ & 1.01 \\
\hline$C_{18: 1 c 11-15}$ & $1.17^{\mathrm{a}}$ & $2.09^{b}$ & 0.19 & $1.08^{a}$ & $2.13^{b}$ & $1.24^{a}$ & $2.25^{b}$ & $1.27^{a}$ & $2.36^{b}$ & $1.25^{a}$ & $2.27^{\mathrm{b}}$ & 0.22 \\
\hline$C_{18: 19-10}$ & $0.71^{a}$ & $2.66^{b}$ & 0.17 & $0.73^{\mathrm{a}}$ & $2.59^{b}$ & $0.81^{a}$ & $2.74^{b}$ & $0.78^{a}$ & $2.61^{b}$ & $0.75^{a}$ & $2.66^{b}$ & 0.21 \\
\hline$C_{18: 1 t 11}$ & $0.59^{a}$ & $1.59^{b}$ & 0.09 & $0.60^{\mathrm{a}}$ & $1.23^{b}$ & $0.68^{a}$ & $1.19^{b}$ & $0.72^{\mathrm{a}}$ & $1.34^{b}$ & $0.70^{\mathrm{a}}$ & $1.28^{b}$ & 0.16 \\
\hline$C_{18: 2 c 9 c 12}$ & 2.25 & 1.98 & 0.11 & 1.92 & 2.02 & 1.95 & 2.00 & 2.06 & 2.14 & 2.02 & 2.08 & 0.14 \\
\hline$C_{18: 3 c 9 c 12 c 15}$ & 0.61 & 0.72 & 0.03 & 0.64 & 0.77 & 0.65 & 0.78 & 0.69 & 0.82 & 0.67 & 0.80 & 0.05 \\
\hline $\mathrm{CLA}^{2}$ & $0.53^{a}$ & $1.53^{b}$ & 0.06 & $0.58^{a}$ & $1.61^{b}$ & $0.64^{a}$ & $1.77^{b}$ & $0.63^{a}$ & $1.80^{\mathrm{b}}$ & 0.61 & $1.78^{b}$ & 0.09 \\
\hline $\mathrm{SFA}^{3}$ & $68.36^{b}$ & $65.48^{a}$ & 2.12 & $68.75^{b}$ & $65.38^{a}$ & $67.77^{b}$ & $64.67^{a}$ & $67.75^{b}$ & $64.20^{\mathrm{a}}$ & $67.92^{b}$ & $64.41^{\mathrm{a}}$ & 2.28 \\
\hline MUFA $^{4}$ & $27.53^{a}$ & $29.57^{b}$ & 1.23 & $27.36^{a}$ & $29.36^{b}$ & $28.17^{a}$ & $29.85^{b}$ & $27.93^{\mathrm{a}}$ & $30.18^{b}$ & $27.80^{\mathrm{a}}$ & $29.98^{b}$ & 1.41 \\
\hline MUFA $c i s^{5}$ & $22.85^{b}$ & $20.64^{a}$ & 0.86 & $22.73^{b}$ & $21.26^{a}$ & $23.20^{b}$ & $21.42^{\mathrm{a}}$ & $23.07^{b}$ & $21.52^{\mathrm{a}}$ & $22.94^{b}$ & $21.56^{\mathrm{a}}$ & 0.98 \\
\hline MUFA trans ${ }^{6}$ & $2.02^{\mathrm{a}}$ & $5.51^{\mathrm{b}}$ & 0.22 & $1.84^{\mathrm{a}}$ & $4.67^{\mathrm{b}}$ & $1.79^{a}$ & $4.90^{\mathrm{b}}$ & $1.86^{\mathrm{a}}$ & $5.02^{b}$ & $1.92^{\mathrm{a}}$ & $4.96^{b}$ & 0.24 \\
\hline PUFA $^{7}$ & $4.11^{\mathrm{a}}$ & $4.95^{b}$ & 0.16 & $3.90^{\mathrm{a}}$ & $5.26^{b}$ & $4.06^{a}$ & $5.49^{b}$ & $4.32^{\mathrm{a}}$ & $5.63^{b}$ & $4.28^{a}$ & $5.61^{b}$ & 0.18 \\
\hline$n-3^{8}$ & 0.99 & 0.96 & 0.04 & 0.97 & 0.85 & 1.03 & 0.97 & 1.15 & 0.88 & 1.09 & 0.93 & 0.05 \\
\hline$n-6^{9}$ & 2.33 & 2.15 & 0.12 & 2.45 & 2.18 & 2.47 & 2.27 & 2.39 & 2.34 & 2.42 & 2.31 & 0.15 \\
\hline
\end{tabular}

${ }^{1}$ see Table $1 ;{ }^{2}$ CLA (C18:2c9t11,C18:2t10c12); ${ }^{3}$ SFA (C4:0, C6:0, C8:0, C10:0, C12:0, C13 iso, C14:0, C15:0, C15 iso, C16:0, C17:0, C17 iso, C18:0, C19:0, C20:0, C22:0, C24:0); ${ }^{4}$ MUFA (C14:1, C16:1, MUFA cis, MUFA trans, C20:1, C22:1, C24:1); ${ }^{5}$ cis-MUFA (C18:1c9, C18:1c11, C18:1c12, C18:1c13, C18:1c14, C18:1c15); ${ }^{6}$ trans-MUFA (C18:1t9, C18:1t10, C18:1t11, C18:1t12, C18:1t15); ${ }^{7}$ PUFA (C18:2 c9 c12, C18:2 c9 c15, C18:2 c9t11, C18:2t10 c12, C18:3 c9 c12 c15, C20:3, C20:4, C22:5, C22:6); ${ }^{8} n-3$ (C18:3 c9 c12 c15, C20:3, C22:5, C22:6); ${ }^{9} n-6$ (C18:2 c9 c12, $\mathrm{C} 20: 2, \mathrm{C} 20: 3, \mathrm{C} 20: 4) ; \mathrm{a}, \mathrm{b}$ mean values within each row in the same time of storage with different superscripts are significantly different $(\alpha=0.05)$; SEM - standard error of the mean

The highest (3.7-fold) rise in the percentage share was found for $\mathrm{C}_{18: 1}$ trans-10 acid. The increase in the share of $\mathrm{C}_{18: 1}$ trans-11 acid was also very high, about 3-fold. An almost twice as high percentage share of monounsaturated fatty acids was found in the case of $\mathrm{C}_{18: 1}$ cis-11-15 acids. The percentage of conjugated dienes of $\mathrm{C}_{18: 2}$ acid was more than 3 times higher. The high content of monounsaturated acids and conjugated dienes of $\mathrm{C}_{18: 2}$ acid resulted in a higher percentage of monounsaturated and polyunsaturated acids in the milk of sheep whose diet was supplemented with Camelina sativa. It is worth stressing that the milk of sheep fed with gold of pleasure had a lower percentage of saturated fatty acids.

In their study on the milk of sheep receiving gold of pleasure cake as a supplement of the feed ration at 100 and $200 \mathrm{~g}$ per sheep per day. Szumacher-Strabel et al. (2011) reported an increase in the share of C18:2 cis- 9 trans- 11 acid by $72 \%$ and $78 \%$, respectively, in comparison with the control. These authors recorded an increase in the share of n-3 fatty acids in both feeding groups by over $50 \%$ and $80 \%$, respectively.
Interesting observations were also made concerning sensory evaluation of the ewe milk produced in this experiment. It was found that the higher level of gold of pleasure supplementation significantly deteriorated quality attributes, particularly aroma, of the produced milk (Cais-Sokolińska et al., 2011). In the context of these data, the supplementation dose used in this study, i.e. $120 \mathrm{~g}$ per sheep a day, seems optimal.

A similar MUFA content was found in milk of Sarda, g $\cdot 100 \mathrm{~g}^{-1}$ : (21.5), Churra (22.1) and crossbreeds of Sarda and Lacaune sheep (20 g), (Carta et al., 2003; Atti et al., 2006; De La Fuente et al., 2009).

Atti et al. (2006) when analysing the fatty acid profile in milk of Sarda ewes fed hay, silage and grain concentrate found a much lower content of PUFA $\left(2.06 \mathrm{~g} \cdot 100 \mathrm{~g}^{-1}\right)$, which indicates that the content of these acids may be more closely related to nutrition than had been assumed. A greater share in pasture sward, especially of $\mathrm{C} 18: 3$, may contribute to the increase of PUFA in the milk of grazing ewes (Talpur et al., 2009). 
According to many authors, feeding is the key factor influencing the content of cis-9, trans-11 $\mathrm{C}_{18: 2}$ in milk. The highest differences were reported between summer feeding (with a large share of green forages) and winter feeding (Nudda et al., 2005). Pasture feeding is a rich source of linolenic acid and provides the precursor (C18:1 trans-11) for endogenous synthesis of CLA. Higher contents of cis-9, trans-11 CLA, in comparison with the results reported in this study, were recorded by Patkowska-Sokola et al. (2005) in the milk of Polish Mountain sheep and Friesian sheep during grazing, amounting to $0.9 \%$ and $0.71 \%$ of the total fatty acids, respectively. In milk of Tsigai and Sarda sheep kept on the pasture, the content of CLA was also higher than that in the present study (Atti et al., 2006). Similar contents of this isomer as in our study were reported by Tsiplakou et al. (2006) in the milk of typical milk breeds such as Awassi (0.46\%), Lacaune (0.44\%), Friesian (0.35\%) and Chios $(0.46 \%)$ sheep that were kept under identical feeding management conditions as in this study.

The differences between fat content in the milk from the sheep in the control and experimental groups influenced the fat content and energy value of the produced yoghurt. In contrast, milk collected from different feeding management groups of sheep had no influence on the active acidity of the produced yoghurt. The three-week refrigerated storage of yoghurt did not affect active acidity in any analysed yoghurt sample (Table 5).

The fatty acid profile of yoghurt produced from the milk of sheep in the control and experimental groups is presented in Table 4. A decreased saturated fatty acid (SFA) content was observed in the yoghurt from the experimental group milk when compared with that from the control group milk $(P<0.05)$, regardless of the storage period. In the yoghurt made from CS milk, the MUFA content was more than 2.5 times greater than in the yoghurt made from the milk of the control (C) animals, both immediately after production and in the 21-day storage pe- riod. During storage the share of PUFA remained at a higher level in the yoghurt produced from the CS milk. The CLA content in the CS yoghurt was more than 2.8 times greater than in that made from the control milk, both immediately after its production and after 3 weeks of storage.

In the study of Hurtaud and Peyraud (2007), a control diet composed of $60 \%$ maize silage-based ration and completed with high-energy and nitrogenous concentrates was compared with two experimental diets designed to provide the same amount of polyunsaturated fatty acids via either camelina seed $\left(630 \mathrm{~g} \cdot \mathrm{d}^{-1}, \mathrm{CS}\right.$ diet $)$ or camelina cake $\left(2 \mathrm{~kg} \cdot \mathrm{d}^{-1}, \mathrm{CC}\right.$ diet). The experiment was realized during a 4 -week period on 6 Holstein dairy cows. The camelina diets tended to decrease dry matter intake but did not have a significant effect on milk production. They generated a slight decrease in milk protein and a strong decrease in milk fat yield and content. The CC diet led to a stronger decrease in fat content. Camelina (CS) generated a greater proportion of monounsaturated fatty acids, notably C18:1 trans isomers, including trans-10 and trans-11 C18:1, which increased by 11.0 - and 2.6-fold, respectively, with the $\mathrm{CC}$ diet. Camelina also led to an increase in conjugated linoleic acids, particularly rumenic acid, cis-9, trans-11 C18:2. Camelina did not affect butter making parameters, except churning time, with milk from CC-fed cows, which was longer (Hurtaud and Peyraud, 2007).

Rodríguez-Alcalá and Fontecha (2007) observed the total fatty acid and CLA contents in dairy products during processing and 10-week refrigerated storage. The tested products in this study included a CLA oil supplement and several skim milk dairy products fortified with the supplement, among others, fermented milk and yoghurt. After 5 weeks of storage, the contents of total CLA and total PUFA, and of cis-9 C18:2, trans-11 CLA and cis-10 C18:2, trans-12 CLA isomers decreased (Rodríguez-Alcalá and Fontecha, 2007). In the work of Campbell et al.

Table 5. Chemical composition and acidity of yoghurt during refrigerated storage

\begin{tabular}{|c|c|c|c|c|c|c|c|c|c|}
\hline \multirow{3}{*}{ Composition $^{1}$} & \multicolumn{9}{|c|}{ Storage time, days } \\
\hline & \multicolumn{2}{|l|}{1} & \multicolumn{2}{|l|}{7} & \multicolumn{2}{|l|}{14} & \multicolumn{2}{|l|}{21} & \multirow{2}{*}{ SEM } \\
\hline & control & $\mathrm{CS}^{1}$ & control & CS & control & CS & control & CS & \\
\hline \multicolumn{10}{|l|}{$\mathrm{g} \cdot \mathrm{kg}^{-1}$} \\
\hline fat & $5.60^{\mathrm{b}}$ & $4.34^{\mathrm{a}}$ & $5.62^{b}$ & $4.39^{a}$ & $5.64^{b}$ & $4.41^{\mathrm{a}}$ & $5.68^{b}$ & $4.43^{\mathrm{a}}$ & 0.05 \\
\hline protein & 4.41 & 4.31 & 4.45 & 4.35 & 4.44 & 4.32 & 4.47 & 4.36 & 0.04 \\
\hline lactose & 4.93 & 4.77 & 4.88 & 4.74 & 4.86 & 4.71 & 4.84 & 4.68 & 0.06 \\
\hline minerals & 0.78 & 0.86 & 0.77 & 0.85 & 0.76 & 0.87 & 0.78 & 0.88 & 0.03 \\
\hline Active acidity, $\mathrm{pH}$ & 4.60 & 4.60 & 4.56 & 4.57 & 4.51 & 4.53 & 4.47 & 4.51 & 0.04 \\
\hline Titratable acidity, ${ }^{\circ} \mathrm{SH}$ & $42.61^{\mathrm{A}}$ & $41.20^{A}$ & $46.81^{A B}$ & $45.69^{A B}$ & $50.70^{B C}$ & $49.30^{\mathrm{BC}}$ & $53.60^{c}$ & $51.84^{\mathrm{C}}$ & 0.07 \\
\hline
\end{tabular}

${ }^{1}$ see Table 1 ; mean values within each row in the same time of storage $\left({ }^{a, b}\right)$ or in the same group $\left({ }^{A, B, C}\right)$ with different superscripts are significantly different $(\alpha=0.05)$; SEM - standard error of the mean 
(2003) a significant loss of cis-9 C18:2, trans-11 CLA after HTST pasteurization of 2\% CLA-fortified skim milk was found. Other results were reported by $\mathrm{Xu}$ et al. (2005) using a combination of mainly probiotic bacteria with yoghurt cultures. In this research on fermented milk products, slightly higher contents of cis-9, trans-11 and trans-10 C18:2 and cis-12 CLA were found.

Interesting results were recorded by CaisSokolińska et al. (2015) in kefir made from milk from dairy goats supplemented with gold of pleasure (CS) at $120 \mathrm{~g}$ per day per head. The administration of CS cake had a positive effect on the fatty acid profile of raw milk and kefir produced from this milk, causing an increase in the proportion of PUFA, including CLA and n-3 fatty acids. Their increased percentage was detected in kefir both immediately after production and after 1, 2 and 3 weeks of storage.

\section{Apparent viscosity, consistency, cohesiveness colour parameters, and taste, flavour and consistency of yoghurt during refrigerated storage}

In this study, sheep milk and yoghurt produced from it are characterized by high viscosity when compared with milk of other animal species and fermented drinks produced from it (Skrzypek et al., 2003; Wójtowski et al., 2003). Viscosity is affected by the diameter of casein micelles and casein protein content. The lowest apparent viscosity values were recorded in yoghurt produced from the CS sheep milk (Table 6). The highest apparent viscosity was found in yoghurt from the $\mathrm{C}$ sheep milk. Also the type of sheep milk (C vs CS) influenced the apparent viscosity of the examined yoghurt. An increase in apparent viscosity was observed only at the end of the storage period.

The texture of yoghurt depended on the type of used milk. Immediately after production, the lowest texture values were recorded for yoghurt produced from $\mathrm{C}$ group sheep milk. At the end of the storage period, the lowest consistency values were found in the yoghurt from $\mathrm{C}$ milk. However, during storage of the examined yoghurts, the consistency values increased depending on the type of milk used (Table 6).

The parameter characterizing the consistency values of analysed yoghurts depended primarily on the type of milk. Negative values of this parameter were higher for yoghurts obtained from the control milk. Negative yoghurt cohesiveness values increased in a statistically significant way with the duration of storage (Table 6).

Despite the absence of differences in titratable acidity and $\mathrm{pH}$ of yoghurt made from milk of sheep from both feeding management groups, differences were observed in the fermentation process. These differences resulted, e.g., in a significantly lower viscosity and cohesiveness of yoghurt made from the milk of ewes receiving the gold of pleasure supplement.

Faster and more abundant growth of streptococci in the initial phase of fermentation may result in excessive development of lactic acid bacteria, which in turn are characterized by a greater capacity to produce exopolysaccharides. Exopolysaccharides are responsible for binding greater amounts of water in the curd. The final product will thus not only have different rheological attributes, but will also give different yields of whey and chrome yellow. This was confirmed by analyses in this experiment. In the case of the experimental yoghurts, it was shown that those produced from the milk of sheep receiving gold of pleasure cake were less light-coloured and had a less saturated yellow colour than yoghurts made from the milk of ewes receiving conventional diets. These observations may prove valuable when planning further experiments connected with analyses of the course of fermentation in the milk of animals fed enriched feeds and which have not been investigated in this study.

The type of milk used (C or CS) had no effect on the brightness of colour in yoghurt. There was a decrease in the $\mathrm{L}^{*}$ value after 14 days of storage

Table 6. Apparent viscosity (mPas), consistency, cohesiveness and colour parameters $\left(\mathrm{L}^{*} \mathrm{a}^{*} \mathrm{~b}^{*}\right)$ and taste, flavour and consistency of yoghurt during refrigerated storage

\begin{tabular}{|c|c|c|c|c|c|c|c|c|c|}
\hline \multirow{3}{*}{ Parameters } & \multicolumn{4}{|c|}{ Storage time, days } & \multirow{2}{*}{\multicolumn{2}{|c|}{14}} & \multirow{2}{*}{\multicolumn{2}{|c|}{21}} & \multirow{3}{*}{ SEM } \\
\hline & \multicolumn{2}{|l|}{1} & \multicolumn{2}{|l|}{7} & & & & & \\
\hline & control & $\mathrm{CS}^{1}$ & control & CS & control & CS & control & CS & \\
\hline Viscosity & $7461^{A}$ & $731^{A}$ & $7520^{A}$ & $7372^{A}$ & $7582^{A B}$ & $7422^{\mathrm{AB}}$ & $7652^{B}$ & $7483^{B}$ & 12.23 \\
\hline Consistency & $11336^{A}$ & $11434^{\mathrm{A}}$ & $11365^{A}$ & $11652^{A}$ & $11533^{B}$ & $11677^{\AA}$ & $12297^{c}$ & $12456^{B}$ & 24.89 \\
\hline Cohesiveness & $-139^{B}$ & $-132^{A}$ & $-138^{A}$ & $-136^{A}$ & $-157^{\mathrm{B}}$ & $-156^{\mathrm{B}}$ & $-185^{c}$ & $-172^{\mathrm{C}}$ & 1.87 \\
\hline$L^{*}(\%)$ & $87^{c}$ & $83^{B}$ & $85^{\mathrm{B}}$ & $83^{\mathrm{ABA}}$ & $84^{\mathrm{BA}}$ & $81^{\mathrm{A}}$ & $82^{A}$ & $81^{\mathrm{A}}$ & 0.21 \\
\hline$a^{*}(-)$ & $-3^{c}$ & $-2^{c}$ & $-2^{A B}$ & $-2^{B C}$ & $-2^{\mathrm{BA}}$ & $-2^{A B}$ & $-2^{A}$ & $-2^{A}$ & 0.03 \\
\hline$b^{*}(-)$ & $10^{c}$ & $g^{B}$ & $g^{B}$ & $g^{B A}$ & $9^{B A}$ & $g^{A}$ & $g^{A}$ & $9^{A}$ & 0.07 \\
\hline
\end{tabular}

${ }^{1}$ see Table 1 ; ${ }^{*}$ mean values within each row in the same group $\left({ }^{A, B, C}\right)$ with different superscripts are significantly differ; SEM - standard error of the mean 
Table 7. Organoleptic evaluation of taste, flavour and consistency of yoghurt during refrigerated storage (10 points scale)

\begin{tabular}{|c|c|c|c|c|c|c|c|c|c|}
\hline \multirow{3}{*}{\multicolumn{2}{|c|}{ Analysed parameters }} & \multicolumn{8}{|c|}{ Storage time, days } \\
\hline & & \multicolumn{2}{|c|}{1} & \multicolumn{2}{|l|}{7} & \multicolumn{2}{|l|}{14} & \multicolumn{2}{|l|}{21} \\
\hline & & control & $\mathrm{CS}^{1}$ & control & CS & control & CS & control & CS \\
\hline \multirow[t]{5}{*}{ Taste } & sweet & 7.9 & 6.9 & 7.7 & 6.9 & 7.5 & 6.7 & 7.1 & 6.5 \\
\hline & sour & 6.2 & 5.5 & 5.9 & 5.6 & 5.6 & 5.1 & 5.4 & 4.5 \\
\hline & buttery & 9.2 & 8.1 & 9.1 & 7.8 & 8.6 & 7.5 & 8.2 & 7.5 \\
\hline & oily & 0.3 & 1.3 & 0.4 & 1.6 & 0.3 & 1.9 & 0.5 & 2.4 \\
\hline & grassy & 1.2 & 0.6 & 1.1 & 0.9 & 1.3 & 1.2 & 1.6 & 0.9 \\
\hline \multirow[t]{4}{*}{ Flavour } & sour & 4.5 & 4.0 & 5.4 & 5.2 & 5.8 & 5.6 & 6.8 & 6.4 \\
\hline & buttery & 6.5 & 6.8 & 6.2 & 6.5 & 6.0 & 6.3 & 5.7 & 6.0 \\
\hline & fermented & 5.2 & 5.0 & 5.6 & 5.3 & 5.8 & 5.5 & 6.0 & 5.7 \\
\hline & grassy & 1.8 & 1.6 & 1.7 & 1.5 & 1.7 & 1.6 & 1.4 & 1.2 \\
\hline \multirow[t]{4}{*}{ Consistency } & springy & 0.2 & 1.6 & 0.2 & 1.5 & 0.3 & 1.7 & 0.4 & 2.2 \\
\hline & homogenous & 9.5 & 9.2 & 9.4 & 9.0 & 9.2 & 8.7 & 9.0 & 8.5 \\
\hline & cohesive & 9.5 & 9.3 & 9.5 & 9.2 & 9.4 & 9.1 & 9.2 & 8.9 \\
\hline & watery & 8.5 & 8.1 & 8.4 & 7.8 & 8.3 & 7.6 & 8.1 & 7.5 \\
\hline
\end{tabular}

${ }^{1}$ see Table 1

of yoghurt. The type of milk used had no influence on colour constituents $\mathrm{a}^{*}$ and $\mathrm{b}^{*}$. In contrast, storage time had an effect on the decrease in the values of constituents $a^{*}$ and $b^{*}$ (Table 6). The values of parameters $a^{*}$ and $b^{*}$ indicate a shift in the colour space towards green and yellow. The white colour of milk is mainly caused by the diffusion of light on colloidal particles of the casein-calcium complex.

The distance from white index values decreased only at the end of the yoghurt storage period, regardless of the type of milk used.

The results of sensory examination of taste, smell and texture of sheep milk yoghurt are presented in Table 7.

Yoghurt produced from the CS milk inoculated with the ABT-1 starter culture differed from that made from the $\mathrm{C}$ milk by a faint oily taste.

These results may be compared to those recorded by Cais-Sokolińska et al. (2015) when evaluating the quality of kefir from milk from goats fed a diet rich in bioactive compounds (gold of pleasure cake). In this study, the processing value of milk did not differ from the quality attributes of milk from the control goats. An increased proportion of bioactive components in goat milk did not result in changes in acidity, texture, colour, flavour, aroma or consistency of the produced kefir (Cais-Sokolińska et al., 2015).

\section{Conclusions}

Feeding sheep with a concentrate supplemented with gold of pleasure cake had no effect on the hygienic and microbiological quality or technological stability of the collected raw milk. Supplementation with a $12 \%$ addition of gold of pleasure cake proved beneficial in terms of the fatty acid profile in milk fat, resulting in an increased share of monounsaturated fatty acids (MUFA), including trans- MUFA, and polyunsaturated fatty acids, including conjugated linoleic acid (CLA). Sheep milk with an increased content of bioactive components was a valuable raw material for yoghurt production. The same advantageous differences in the composition of fatty acids were found in yoghurt produced from milk in the experimental group both immediately after its production and after 21 days of storage. Taking into consideration the results of both the instrumental analysis and sensory examination, it was shown that the yoghurt produced from sheep milk with an increased content of biologically active components did not differ significantly in quality from that made from milk of sheep drown the control group.

\section{Acknowledgement}

This research was conducted under the Project 'Biofood - innovative, functional animal products', financed by the Polish Ministry of Economy within the European Regional Development Fund 2007-2013, Operating Program Innovative Economy No. POIG 01.01.02-014-090/09.

\section{References}

AOAC, 1995. Association of Official Analytical Chemists, Official Methods of Analysis. $16^{\text {th }}$ Edition. Washington, DC

AOAC, 2007. Association of Official Analytical Chemists, Official Methods of Analysis. $18^{\text {th }}$ Edition. Gaithersburg, MD

Atti N., Rouissi H., Othmane M.H., 2006. Milk production, milk fatty acid composition and conjugated linoleic acid (CLA) content in dairy ewes raised on feedlot or grazing pasture. Livest. Sci. 104, 121-127 
Bárcenas F.J., Pérez-Elortondo F.J., Salmerón J., Albisu M., 2001. Sensory profile of ewe's milk cheeses. Food Sci. Techol. Int. 7, 347-353

Blasi F., Montesano D., De Angelis M., Maurizi A., Ventura F., Cossignani L., Simonetti M.S., Damiani P., 2008. Results of stereospecific analysis of triacylglycerol fraction from donkey, cow, ewe, goat and buffalo milk. J. Food Compos. Anal. 21, 1-7

Brennan C.S., Tudorica C.M., 2008. Carbohydrate-based fat replacers in the modification of the rheological, textural and sensory quality of yoghurt: comparative study of the utilisation of barley betaglucan, guar gum and inulin. Int. J. Food Sci. Tech. 43, 824-833

Cais-Sokolińska D., Majcher M., Pikul J., Bielińska S., Czauderna M., Wójtowski J., 2011. The effect of Camelina sativa cake diet supplementation on sensory and volatile profiles of ewe's milk. Afr. J. Biotechnol. 10, 7245-7252

Cais-Sokolińska D., Pikul J., Wójtowski J., Danków R., Teichert J., Czyżak-Runowska G., Bagnicka E., 2015. Evaluation of quality of kefir from milk obtained from goats supplemented with a diet rich in bioactive compounds. J. Sci. Food Agric. 95, 1343-1349, doi: 10.1002/jsfa.6828

Campbell W., Drake M.A., Larick D.K., 2003. The impact of fortification with conjugated linoleic acid (CLA) on the quality of fluid milk. J. Dairy Sci. 86, 43-51

Carta A., Piredda G., Addis M., Cabiddu A., Fiori M., Leroux C., Barillet F., 2003. Fatty acid composition of sheep milk from a backcross Sarda x Lacaune resource population: Preliminary QTL detection for CLA content. In: D. Gabiña, S. Sanna (Editors). Breeding Programmes for Improving the Quality and Safety of Products. New Traits, Tools, Rules and Organization? Zaragoza (Spain), pp. 107-113

Cieślak A., Machmüller A., Szumacher-Strabel M., Scheeder M.R.L., 2009. A note on comparison of two extraction methods used to quantify $\mathrm{C} 18$ fatty acids in feed and digesta of ruminants. J. Anim. Feed Sci. 18, 362-367

Collomb M., Bühler T., 2000. Analyse de la composition en acides gras de la graisse de lait, I. Optimisation et validation d'une méthode générale à haute résolution. Trav. Chim. Aliment. Hyg. 91, 306-332

Collomb M., Schmid A., Sieber R., Wechsler D., Ryhänen E.-L., 2006. Conjugated linoleic acids in milk fat. Variation and physiological effects. Int. Dairy J. 16, 1347-1361

Danków R., Pikul J., 2011. Technological suitability of sheep milk for processing (in Polish). Nauka Przyr. Technol. 5 (2), \#7, 1-20

De La Fuente L.F., Barbosa E., Carriedo J.A., Gonzalo C., Arenas R., Fresno J.M., San Primitivo F., 2009. Factors influencing variation of fatty acid content in ovine milk. J. Dairy Sci. 92, 3791-3799

DIN 53019-1. Viscometry - Measurement of viscosities and flow curves by means of rotational viscometers - Part 1: Principles and measuring geometry. Standard by Deutsches Institut für Normung E.V. 09.08.2008 (German National Standard)

Gorshkova T.B., 2005. Provision of uniformity for measurement of color characteristics in the paint, food, textile, and other branches of industry. Meas. Tech. 48, 1096-1098

Hurtaud C., Peyraud J.L., 2007. Effects of feeding camelina (seeds or meal) on milk fatty acid composition and butter spreadability. J. Dairy Sci. 5134-5145

Isleten M., Karagul-Yuceer Y., 2006. Effects of dried dairy ingredients on physical and sensory properties of nonfat yoghurt. J. Dairy Sci. 89, 2865-2872

ISO 6611, 2004. Milk and milk products - Enumeration of colony-forming units of yeasts and/or moulds - Colony-count technique at 25 degrees C. International Organization for Standardization. Geneva (Switzerland)

Markiewicz-Kęszycka M., Wójtowski J., Czyżak-Runowska G., Kuczyńska B., Puppel K., Krzyżewski J., Strzałkowska N., Jóźwik A., Bagnicka E., 2014. Concentration of selected fatty acids, fat-soluble vitamins and $\beta$-carotene in late lactation mares' milk. Int. Dairy J. 38, 31-36

Marshall V.M., Rawson H.L., 1999. Effects of exopolysaccharideproducing strains of thermophilic lactic acid bacteria on the texture of stirred yoghurt. Int. J. Food Sci. Tech. 34, 137-143

Meluchová B., Blaško J., Kubinec R., Góraková R., Dubravska J., Margetin M., Soják L., 2008. Seasonal variations in fatty acid composition of pasture forage plants and CLA content in ewe milk fat. Small Ruminant Res. 78. 56-65

Mughetti L., Sinesio F., Acuti G., Antonini C., Moneta E., Peparaio M., Trabalza-Marinucci M., 2012. Integration of extruded linseed into dairy sheep diets: Effects on milk composition and quality and sensorial properties of Pecorino cheese. Anim. Feed Sci. Tech. 178, 27-39

Myers D., 2007. Probiotics. J. Exotic Pet Med. 16, 195-197

Nudda A., McGuire M.A., Battacone G., Pulina G., 2005. Seasonal variation in conjugated linoleic acid and vaccenic acid in milk fat of sheep and its transfer to cheese and ricotta. J. Dairy Sci. $88,1311-1319$

Park Y., 2009. Conjugated linoleic acid (CLA): Good or bad trans fat? J. Food Compos. Anal. 22, Suppl., S4-S12

Patkowska-Sokola B., Ramadani S., Bodkowski R., 2005. Milk chemical composition of Polish Mountain sheep and Fresian sheep during the grazing season (in Polish). Rocz. Nauk Zoot., Suppl. 21, 73-76

Pikul J., Wójtowski J., Danków R., Kuczyńska B., Łojek J., 2008. Fat content and fatty acids profile of colostrum and milk of primitive Konik horses (Equus caballus gmelini Ant.) during six months of lactation. J. Dairy Res. 75, 302-309

Rodríguez-Alcalá L.M., Fontecha J., 2007. Fatty acid and conjugated linoleic acid (CLA) isomer composition of commercial CLAfortified dairy products: evaluation after processing and storage. J. Dairy Sci. 90, 2083-2090

SAS, 2008. Users Guide, Version 9.1. SAS Institute Inc. Cary, NC

Sieber R., Collomb M., Aeschlimann A., Jelen P., Eyer H., 2004. Impact of microbial cultures on conjugated linoleic acid in dairy products - a review. Int. Dairy J. 14, 1-15

Skrzypek R., Wójtowski J., Fahr R.-D., 2003. Hygienic quality of cow bulk tank milk depending on the method of udder preparation for milking. Arch. Tierzucht 46, 405-411

StatSoft, Inc. STATISTICA, 2011. Data analysis software system, ver. 8. www.statsoft.com

Szumacher-Strabel M., Cieślak A., Zmora P., Pers-Kamczyc E., Bielińska S., Stanisz M., Wójtowski J., 2011. Camelina sativa cake improved unsaturated fatty acids in ewe's milk. J. Sci. Food Agric. 91, 2031-2037

Talpur F.N., Bhanger M.I., Memon N.N., Nusrat N, 2009. Milk fatty acid composition of indigenous goat and ewe breeds from Sindh, Pakistan. J. Food Compos. Anal. 22, 59-64

Tsiplakou E., Mountzouris K.C., Zerves G., 2006. The effect of breed, stage of lactation and parity on sheep milk fat CLA content under the same feeding practices. Livest. Sci. 105, 162-167

van Soest P.J., Robertson J.B., Lewis B.A., 1991. Methods for dietary fiber, neutral detergent fiber, and non starch polysaccharides in relation to animal nutrition. J. Dairy Sci. 74, 3583-3597

Wójtowski J., Danków R., Skrzypek R., Fahr R.-D., 2003. The fatty acid profile in kefirs from sheep, goat and cow milk. Milchwissenschaft. 58, 633-636

Xu S., Boylston T.D., Glatz B.A., 2005. Conjugated linoleic acid content and organoleptic attributes of fermented milk products produced with probiotic bacteria. J. Agric. Food Chem. 53, 9064-9072

Zubr J., 1997. Oil-seed crop: Camelina sativa. Ind. Crop Prod. 6, 113-119 